\title{
OPTIMISASI PENJADWALAN EKONOMIS PADA UNIT PEMBANGKIT PLTG DI PLTGU PT INDONESIA POWER TAMBAK LOROK MENGGUNAKAN METODE DIFFERENTIAL EVOLUTION ALGORITHM
}

\author{
Achmad Faizal Tamin*), Karnoto, dan Mochammad Facta \\ Departemen Teknik Elektro, Universitas Diponegoro \\ Jl. Prof. Sudharto, SH, kampus UNDIP Tembalang, Semarang 50275, Indonesia \\ *) E-mail : faizaltamin.94@gmail.com
}

\begin{abstract}
Abstrak
Biaya pembangkitan merupakan biaya penyediaan energi listrik terbesar terutama pada biaya bahan bakar. Setiap unit generator memiliki karakteristik biaya pembangkitan tersendiri. Untuk mendapatkan pengoperasian pembangkit yang optimal maka diperlukan adanya penjadwalan operasi pembangkit. Differential Evolution Algorithm (DEA) diusulkan sebagai metode penjadwalan ekonomis pada PLTG di PLTGU Tambak Lorok. Metode DEA merupakan metode pencarian yang terinsiparasi oleh fenomena evolusi di alam dengan dasar argumen geometri. Untuk melihat perfoma dari simulasi metode DEA maka metode ini dibandingkan dengan metode Lagrange Mulptiplier sebagai validasi. Hasil simulasi optimisasi dengan metode DEA menunjukkan performa yang baik. Hasil simulasi identik dengan metode Lagrange Mulptiplier, sedangkan dalam keadaan operasi sistem dan keadaan diskret tidak memiliki perbedaan yang signifikan. Berdasarkan simulasi dengan dua kondisi operasi yang berbeda menggunakan metode DEA, didapatkan bahwa pada operasi diskret didapat rata-rata penghematan sebesar 1916,260 \$/jam. Pada operasi sistem didapat rata-rata penghematan sebesar 1914,408 \$/jam.
\end{abstract}

Kata kunci : penjadwalan ekonomis, DEA, biaya pembangkitan, lagrange multiplier

\begin{abstract}
The biggest cost to supply electric power is the generation cost, especially the fuel cost. Each generator unit has generating cost characteristics. In order to obtain optimal operation of the plant, the economic dispatch is required. Differential Evolution Algorithm (DEA) is proposed as an generation scheduling method for Gas Power Plant (PLTG) at Gas and Steam Power Plant (PLTGU) Tambak Lorok. The DEA method is a method based on evolutionary phenomena in nature with basic geometric argument. To see the performance of the DEA method simulation, this method is compared with Lagrange Mulptiplier as a validation. The simulation results show good performance, as the results of DEA is identical with Lagrange Multiplier method, and there is no significant diferrence in system operation and discrete condition. The results of DEA simulation with two different operation are obtained with an average savings of the cost as much as 1916,260 \$/hour in discrete condition and 1914,408 \$/hour in system operation condition.
\end{abstract}

Keywords : economic dispatch, DEA, generation cost, lagrange multiplier

\section{Pendahuluan}

Proses pembangkitan tenaga listrik merupakan perubahan energi primer menjadi energi listrik yang di lakukan oleh generator. Dari segi ekonomi komponen biaya penyediaan tenaga listrik terbesar adalah biaya pembangkitan, khususnya bahan bakar sedangkan pada unit-unit pembangkit tenaga listrik memiliki karakteristik yang berbeda-beda dalam hal biaya pembangkitannya [1]. Agar menghasilkan operasi pembangkitan yang optimal dalam memenuhi variasi perubahan beban maka penjadwalan pengoperasian suatu generator pada pembangkit dan koordinasi antar pembangkitan sangat diperlukan dalam upaya melakukan optimalisasi pembebanan yang bertujuan untuk memperoleh biaya operasi yang optimal dan ekonomis dengan memperhatikan batasan - batasan dari kapasitas unit pembangkit itu sendiri [2], [3].

Untuk mendapatkan biaya operasi yang optimal dan ekonomis, berbagai teknik optimasi telah diterapkan. Salah satu metode solusi untuk menyelesaikan permasalahan optimisasi ini yaitu dengan menggunakan metode Differential Evolution Algorithm (DEA). DEA merupakan salah satu dari banyak metode optimisasi yang digunakan untuk menyelesaikan permasalahan Economic Dispatch. Algoritma ini terinspirasi oleh fenomena evolusi di alam dengan dasar argumen geometri. Algoritma DEA ini memiliki beberapa keunggulan diantaranya konvergensi yang baik, cepat, dan sederhana 
[4]. Penelitian mengenai penerapan metode DEA pada permasalahan economic dispatch telah dilakukan sebelumnya yaitu pada sistem tenaga listrik 26 bus dan sistem kelistrikan Jawa-Bali $500 \mathrm{kV}$ [5].

Pembangkit Listrik Tenaga Gas dan Uap (PLTGU) Tambak Lorok merupakan salah satu pembangkit yang menyuplai kebutuhan tenaga listrik di sistem Jawa-Bali. PLTGU Tambak Lorok memiliki 3 unit PLTG pada blok 1 dan 3 unit PLTG blok 2 serta mempunyai fungsi karakteristik bahan bakar yang berbeda. Pada saat ini biaya operasi PLTGU memanfaatkan gas alam yang dihargai Dolar Amerika Serikat (US\$). Pada penelitian sebelumnya digunakan metode optimisasi Ant Colony Optimization for Continuous Domains $\left(\mathrm{ACO}_{\mathrm{R}}\right)$, Flower Pollination Algorithm (FPA), dan Improved Whale Optimization Algorithm (IWOA) sebagai solusi dari masalah penjadwalan ekonomis pada unit Pembangkit Listrik Tenaga Gas (PLTG) di PLTGU blok 1 dan blok 2 Tambak Lorok [6]-[8].

Dalam penelitian ini, penulis membahas penjadwalan ekonomis menggunakan metode Differential Evolution Algorithm (DEA) pada unit PLTG blok 1 dan blok 2 di PLTGU Tambak Lorok dengan daya keluaran generator yang terhubung pada satu bus utama yang sama. Hasil dari penelitian ini adalah kombinasi daya yang dibangkitkan oleh tiap-tiap generator dan biaya pembangkitan yang ekonomis. Untuk membuktikan keakuratan metode DEA yang diajukan penulis maka hasil simulasi program DEA pada 3 unit pembangkit yang beroperasi berdasarkan konsumsi energi paling kecil (secara diskret) divalidasi menggunakan hasil dari metode Iterasi Lambda (Lagrange Multiplier) secara perhitungan manual [9], [10].

\section{Metode}

\subsection{Metode Penelitian}

Penelitian ini dilaksanakan dalam beberapa tahap penelitian. Pada Gambar 1 dapat dilihat langkah-langkah metode penelitian dalam penelitian ini.

Pada tahap awal dilakukan penentuan fungsi karakteristik tiap unit pembangkit berdasarkan rata-rata keluaran energi terhadap daya yang dihasilkan menggunakan regresi polinomial. Kemudian membuat program simulasi economic dispatch dengan DEA. Setelah itu dilakukan perbandingan hasil simulasi program DEA pada 3 unit pembangkit dengan metode perhitungan Lagrange Multiplier untuk melihat keakuratan hasil dari simulasi metode DEA yang didapat. Kemudian metode DEA disimulasikan menggunakan MATLAB R2016a untuk mencari hasil terbaik dari kombinasi unit pembangkit (GTG) yang terdapat di blok 1 dan blok 2. Simulasi optimisasi unit pembangkit dilakukan dalam dua kondisi yaitu secara diskret dan secara operasi sistem. Secara diskret berarti pembangkit listrik beroperasi hanya melihat konsumsi energi yang paling kecil dan tidak memperhitungkan kondisi operasi. Secara operasi sistem berarti pembangkit listrik beroperasi secara terus menerus setelah dinyalakan sesuai dengan berubahnya permintaan daya dan berdasarkan konsumsi energi yang paling kecil. Kemudian hasil dari optimisasi DEA secara diskret dan secara operasi sistem dibandingkan dengan data pembebanan PLTG di PLTGU Tambak Lorok dan dianalisis berdasarkan konsumsi energi dan total biayanya.

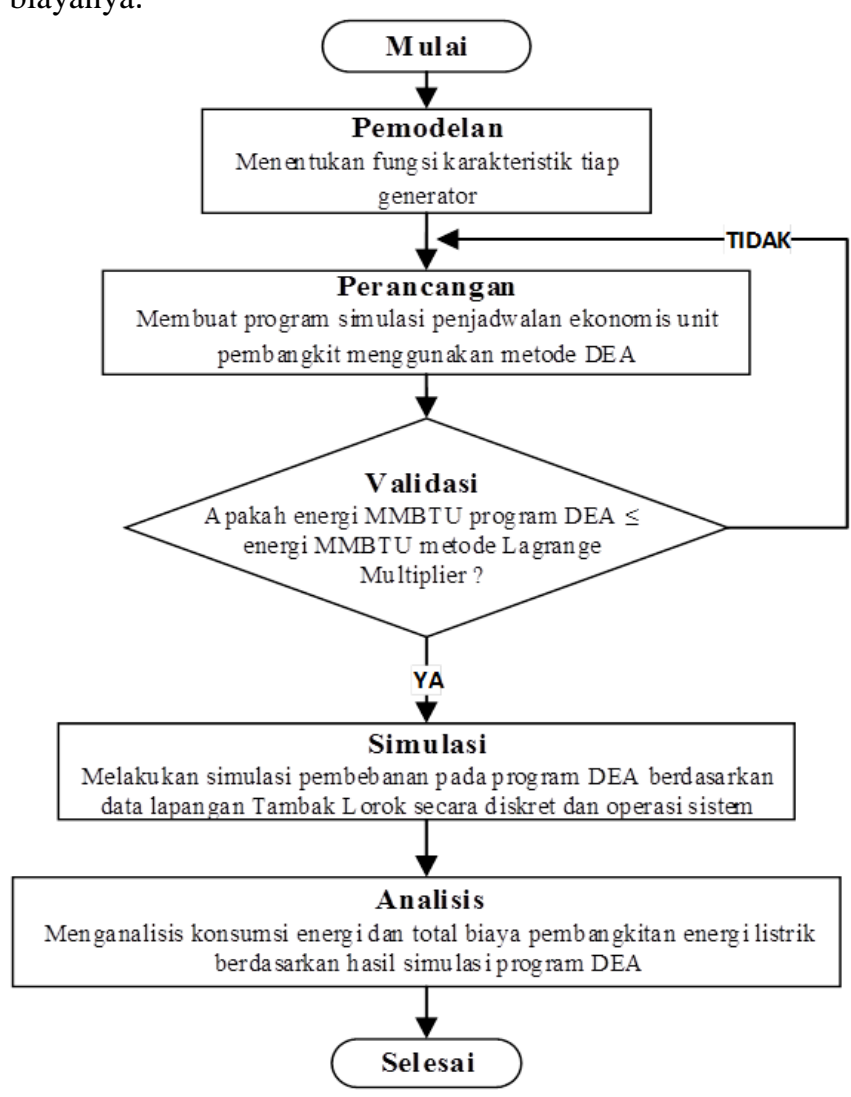

Gambar 1. Diagram alir penelitian

\subsection{Perancangan Sistem}

Secara umum fungsi tujuan dari program simulasi ini adalah penjadwalan pendistribusian beban optimal pada masing-masing unit pembangkit PLTG di PLTGU Tambak Lorok untuk permintaan daya tertentu dengan mempertimbangkan batasan dari masing-masing generator itu sendiri sehingga permintaan daya dapat dipenuhi dengan biaya pembangkitan yang seminimal mungkin. Fungsi tujuan dari optimisasi economic dispatch ini dinyatakan dalam fungsi biaya bahan bakar dari unit pembangkit yang sesuai dengan Persamaan 1[11]

$$
C_{i}=\alpha_{i}+\beta_{i} P_{i}+\gamma_{i} P_{i}^{2}
$$

Dimana,

$C_{i} \quad=$ biaya bahan bakar (masukan unit $i$ ), dollar/jam

$P_{i} \quad=$ daya yang dihasilkan (keluaran unit $i$ ), MW

$\alpha_{i}, \beta_{i}, \gamma_{i}=$ konstanta 
1. Kapasitas unit pembangkit

Generator dari setiap unit pembangkit seharusnya membangkitkan daya tidak melebihi nilai maksimumnya serta tidak boleh dioperasikan untuk membangkitkan daya dibawah nilai minimumnya. Pada PLTG, pembebanan kurang dari beban minimum menyebabkan pembakaran yang kurang sempurna dan menyebabkan turunnya efesiensi.. Dalam hal ini unit PLTG Tambak Lorok memiliki batasan sebagai berikut.

Tabel 1. Batasan PLTG Tambak Lorok

\begin{tabular}{ccc}
\hline Generator & $\begin{array}{c}\text { Batas Bawah } \\
(\mathrm{MW})\end{array}$ & $\begin{array}{c}\text { Batas Atas } \\
(\mathrm{MW})\end{array}$ \\
\hline GTG 1.1 & 30 & 109 \\
GTG 1.2 & 30 & 109 \\
GTG 1.3 & 30 & 109 \\
GTG 2.1 & 30 & 109 \\
GTG 2.2 & 30 & 109 \\
GTG 2.3 & 30 & 109 \\
\hline
\end{tabular}

2. Keseimbangan pembebanan ${ }_{i=1}^{N} \sum P_{i}=P_{D}$

Total pembebanan $\mathrm{P}_{\mathrm{i}}$ adalah sama dengan besarnya permintaan daya $P_{D}$ dan tidak mempertimbangkan rugi-rugi transmisi.

\subsection{Pemodelan Unit-Unit Pembangkit}

Berikut merupakan pemodelan pembangkit dari 6 unit Gas Turbine Generator (GTG) di PLTGU PT Indoesia Power Tambak Lorok.

\section{a. Unit GTG 1.1}

Grafik fungsi kuadratis karakteristik pembangkit Unit 1.1 dapat dilihat pada Gambar 2

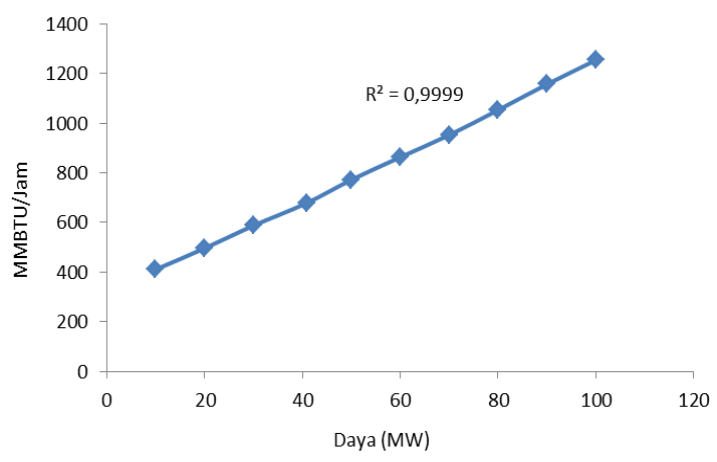

Gambar 2. Grafik karakteristik pembangkit unit 1.1, Keluaran energi (MMBTU/Jam) terhadap Daya (MW)
Persamaan karakteristik pembangkit unit 1.1 dalam Gambar 2 adalah

$\mathrm{C}_{1.1}=326,43+8,3344 \mathrm{P}+0,0094 \mathrm{P}^{2}$

\section{b. Unit GTG 1.2}

Grafik fungsi kuadratis karakteristik pembangkit Unit 1.2 dapat dilihat pada Gambar 3

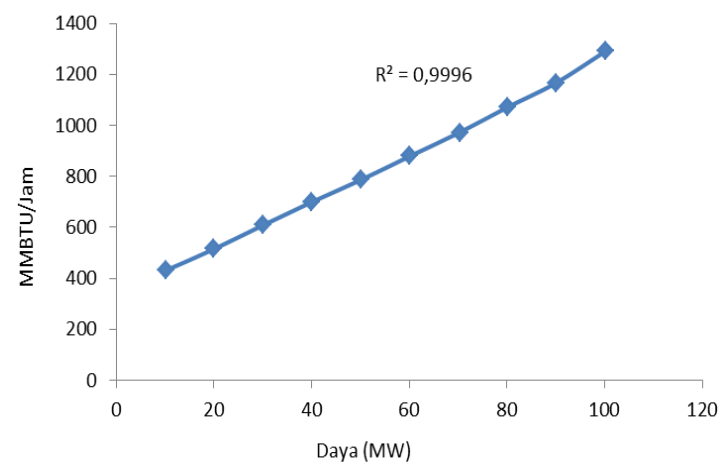

Gambar 3. Grafik karakteristik pembangkit unit 1.2, Keluaran energi (MMBTU/Jam) terhadap Daya (MW)

Persamaan karakteristik pembangkit unit 1.2 dalam Gambar 3 adalah

$\mathrm{C}_{1.2}=352,94+7,984 \mathrm{P}+0,0128 \mathrm{P}^{2}$

c. Unit GTG 1.3

Grafik fungsi kuadratis karakteristik pembangkit Unit 1.3 dapat dilihat pada Gambar 4

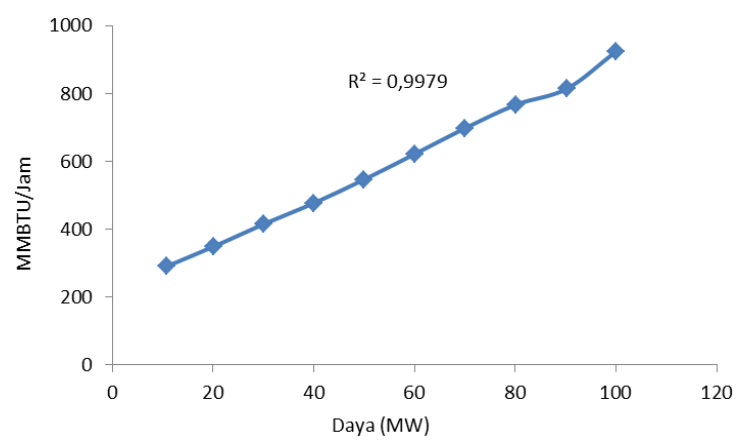

Gambar 4. Grafik karakteristik pembangkit unit 1.3, Keluaran energi (MMBTU/Jam) terhadap Daya (MW)

Persamaan karakteristik pembangkit unit 1.3 dalam Gambar 4 adalah

$\mathrm{C}_{1.3}=223,35+6,1106 \mathrm{P}+0,0078 \mathrm{P}^{2}$

d. Unit GTG 2.1

Grafik fungsi kuadratis karakteristik pembangkit Unit 2.1 dapat dilihat pada Gambar 5 


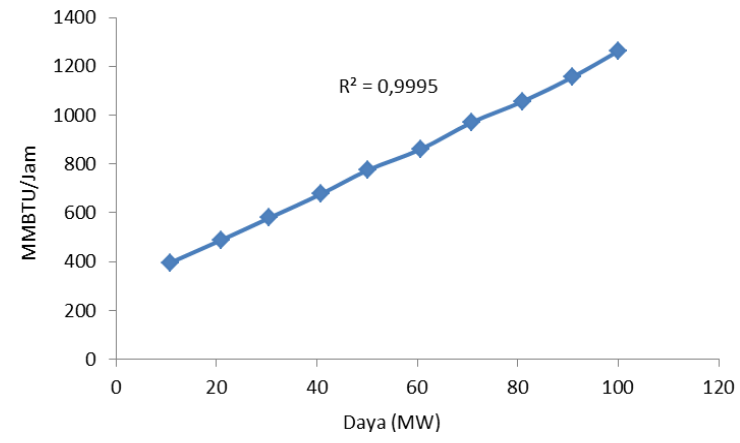

Gambar 5. Grafik karakteristik pembangkit unit 2.1, Keluaran energi (MMBTU/Jam) terhadap Daya (MW)

Persamaan karakteristik pembangkit unit 2.1 dalam Gambar 5 adalah

$\mathrm{C}_{2.1}=298,44+9,0663 \mathrm{P}+0,005 \mathrm{P}^{2}$

e. Unit GTG 2.2

Grafik fungsi kuadratis karakteristik pembangkit Unit 2.2 dapat dilihat pada Gambar 6

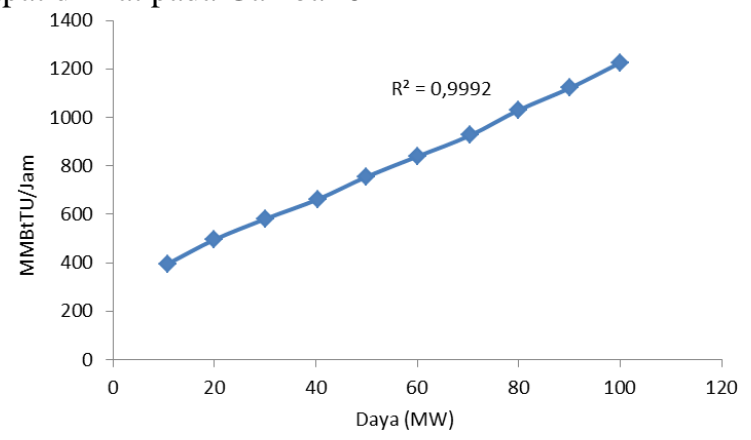

Gambar 6.qGrafik karakteristik pembangkit unit 2.2, Keluaran energi (MMBTU/Jam) terhadap Daya (MW)

Persamaan karakteristik pembangkit unit 2.2 dalam Gambar 6 adalah

$\mathrm{C}_{2.2}=317,63+8,2875 \mathrm{P}+0,0075 \mathrm{P}^{2}$

\section{f. Unit GTG 2.3}

Grafik fungsi kuadratis karakteristik pembangkit Unit 2.3 dapat dilihat pada Gambar 7

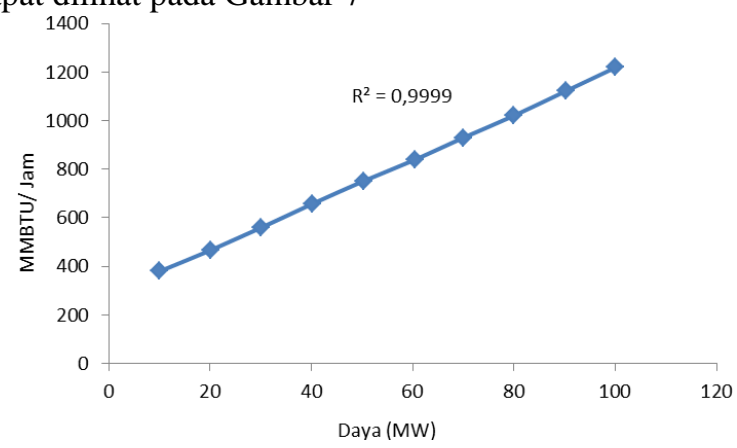

Gambar 7. Grafik karakteristik pembangkit unit 2.3, Keluaran energi (MMBTU/Jam) terhadap Daya (MW)
Persamaan karakteristik pembangkit unit 2.3 dalam Gambar 7 adalah $\mathrm{C}_{2.3}=289,26+8,9351 \mathrm{P}+0,0033 \mathrm{P}^{2}$

\subsection{Perancangan Metode DEA}

Metode optimisasi untuk penjadwalan ekonomis pada penelitian ini adalah Differential Evolution Agorithm (DEA). DEA merupakan pengembangan dari algoritma genetika namun dalam aplikasinya menggunakan argumen geometri. Metode ini diperkenalkan oleh Rainer Storn dan Kenneth V. Price pada tahun 1995 sebagai sebuah metode metaheuristik untu memecahkan permasalahan kontinu [12]. DEA didasari oleh pemanfaatan perbedaan individu didalam populasi utuk melakukan pencarian solusi. DEA memiliki keunggulan dalam hal komputasi yang cepat, konvergensi yang baik, dan sederhana.

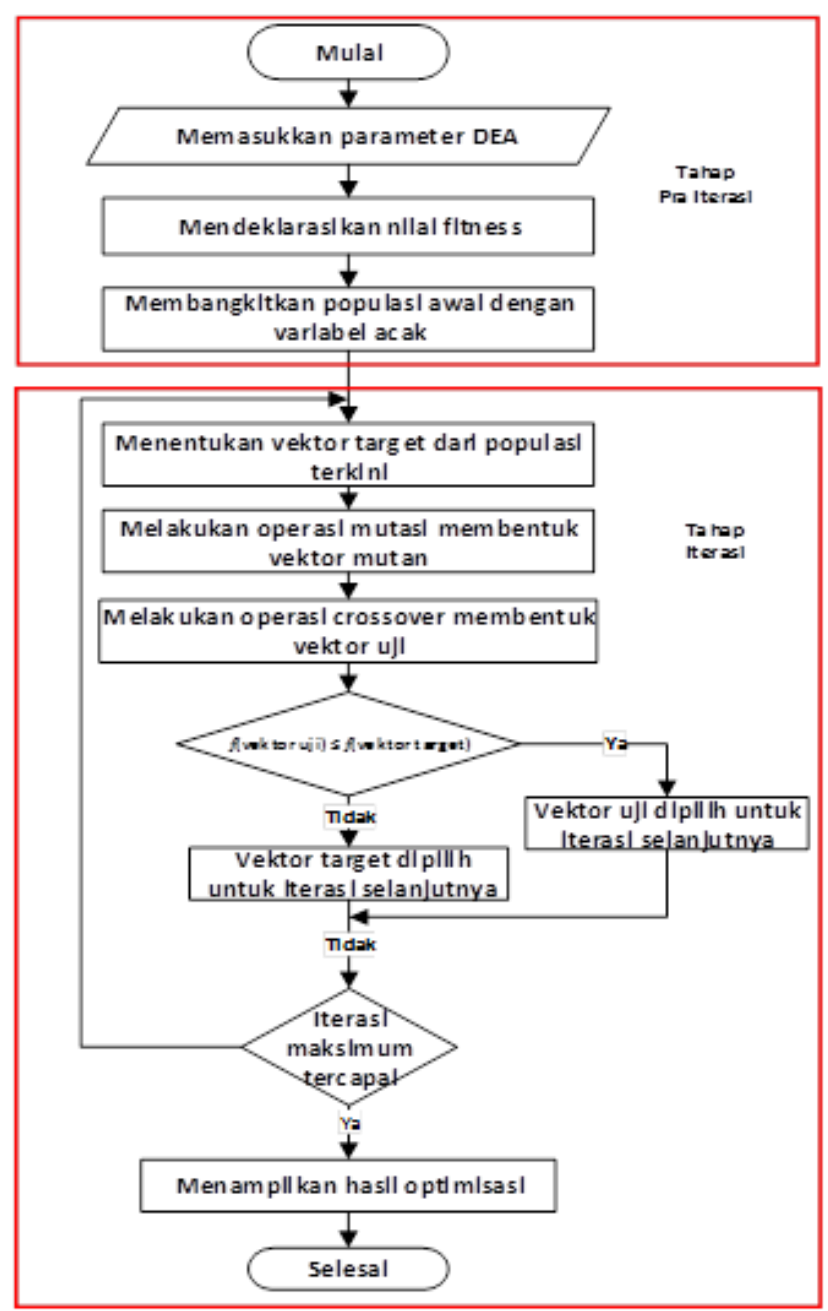

Gambar 8. Diagram alir metode DEA

Pada Gambar 8. memperlihatkan diagram alir metode optimisasi DEA dengan tahap pra iterasi dan tahap iterasi. Berikut penjelasan dari diagram alir pada Gambar 8 . 
a. Tahap pra-iterasi DEA

Tahap pra-iterasi adalah tahapan yang dilakukan sebelum di mulainya proses iterasi DEA. Pada tahap pra-iterasi algoritma di mulai dengan memasukkan parameter DEA yaitu:

jumlah populasi $=200$

$\mathrm{F} \quad=0,3$

$\mathrm{CR} \quad=0,9$

iterasi maksimum $=200$

Selanjutnya mendeklarasikan nilai fitness yang diambil dari persamaan karakteristik masing-masing unit pembangkit. Kemudian menentukan vektor terbaik (daya aktif) dari populasi awal yang dibangkitkan secara acak.

\section{b. Tahap iterasi DEA}

Pada tahap ini terjadi looping utama dari DEA. Tahap ini dimulai dengan mencari vektor uji melalui proses mutasi dan rekombinasi. Kemudian membandingkan nilai fitness dari vektor uji (daya aktif) dengan vektor terbaik (daya aktif) sebelumnya sebagai landasan untuk menetukan vektor terbaik yang baru. Simulasi akan mendapatkan solusi akhir setelah mencapai konvergensi atau mencapai iterasi maksimum.

\section{Hasil dan Analisa}

\subsection{Validasi Metode DEA dengan Metode Lagrange Multiplier}

Perbandingan metode DEA dengan metode Lagrange Multiplier ini dilakukan untuk mengetahui keakuratan program yang telah dibuat sudah berjalan sesuai dengan perhitungan secara manual. Keberhasilan program diukur dari kemampuannya untuk menganalisis pendistribusian beban yang optimal sehingga daya yang dibangkitkan pada masing-masing unit memenuhi batas yang telah ditentukan dan juga energi yang dihemat dari pendistribusian beban mencapai nilai maksimum.

\subsubsection{Perbandingan DEA dengan Lagrange Multiplier}

Berikut adalah contoh perhitungan metode Lagrange Multiplier pada Blok 1 untuk permintaan daya $230 \mathrm{MW}$ :

Diasumsikan $\lambda=9,5$

Untuk iterasi pertama P1, P2 dan P3 adalah

$P_{1}^{(1)}=\frac{9,5-9,0663}{0,01}=43,370$

$P_{2}^{(1)}=\frac{9,5-8,2875}{0,015}=80,833$

$P_{3}^{(1)}=\frac{9,5-8,9351}{0,0066}=85,591$

$\Delta P^{(1)}=230-(43,370+80,833+85,591)=20,206$

Maka perubahan lamda dihasilkan

$$
\Delta \lambda^{(1)}=\frac{20,206}{\frac{1}{0,01}+\frac{1}{0,015}+\frac{1}{0,0066}}=0,064
$$

Kemudian nilai $\lambda$ baru adalah

$\lambda^{(2)}=9,5+0,064=9,564$

Dilanjutkan pada proses iterasi ke-2

$P_{1}^{(2)}=\frac{9,564-9,0663}{0,01}=49,720$

$P_{2}^{(2)}=\frac{9,564-8,2875}{0,015}=85,067$

$P_{3}^{(2)}=\frac{9,564-8,9351}{0,0066}=95,213$

$\Delta P^{(2)}=230-(49,720+85,067+95,213)=0$

$\Delta \lambda^{(2)}=0$

$\Delta P^{(2)}=0$, dan $\Delta \lambda^{(2)}=0$ maka proses iterasi telah selesai. Dihasilkan kombinasi generator dan lamda sebagai berikut

$P_{1}=49,720 \mathrm{MW}$
$P_{2}=85,067 \mathrm{MW}$
$P_{3}=95,213 \mathrm{MW}$
$\lambda=9,564 \frac{\mathrm{MMBTU}}{\mathrm{MWh}}$

Energi masing masing pembangkit adalah

$$
\begin{aligned}
C_{1} & =298,44+9,0663(49,720)+0,005(49,720)^{2} \\
& =761.580 \\
C_{2} & =317,63+8,2875(85,067)+0.0075(85,067)^{2} \\
& =1076.895 \\
C_{3} & =289,26+8,9351(95,213)+0,0033(95,213)^{2} \\
& =852.722
\end{aligned}
$$

Energi total pada saat permintaan daya $230 \mathrm{MW}$ adalah $C_{\text {Ttotal }}=C_{1}+C_{2}+C_{3}=3.008,386 \mathrm{MMBTU} / \mathrm{h}$

Hasil pengujian simulasi dari metode DEA dan metode Lagrange Multiplier menghasilkan daya keluaran dan energi total untuk tiga pembangkit pada blok 2 yang dapat dilihat pada Tabel 2 dan Tabel 3 .

Tabel 2. Hasil perhitungan lagrange multiplier

\begin{tabular}{ccccc}
\hline $\begin{array}{c}\text { Daya } \\
\text { (MW) }\end{array}$ & $\begin{array}{c}\text { GTG 1.1 } \\
\text { (MW) }\end{array}$ & $\begin{array}{c}\text { GTG 1.2 } \\
\text { (MW) }\end{array}$ & $\begin{array}{c}\text { Lagrange } \\
\text { GTG 1.3 } \\
\text { (MW) }\end{array}$ & $\begin{array}{c}\text { Total Energi } \\
\text { (MMBTU/Jam) }\end{array}$ \\
\hline 230 & 49,720 & 85,067 & 95,213 & $3.008,386$ \\
265 & 62,448 & 93,552 & 109 & $3.345,086$ \\
300 & 83,448 & 107,552 & 109 & $3.687,939$ \\
\hline
\end{tabular}

Tabel 3. Hasil simulasi DEA

\begin{tabular}{ccccc}
\hline $\begin{array}{c}\text { Daya } \\
\text { (MW) }\end{array}$ & $\begin{array}{c}\text { GTG 1.1 } \\
\text { (MW) }\end{array}$ & $\begin{array}{c}\text { GTG 1.2 } \\
\text { (MW) }\end{array}$ & $\begin{array}{c}\text { DEA } \\
\text { GTG 1.3 } \\
\text { (MW) }\end{array}$ & $\begin{array}{c}\text { Total Energi } \\
\text { (MMBTU/Jam) }\end{array}$ \\
\hline 230 & 49,793 & 85,012 & 95,195 & $3.008,386$ \\
265 & 62,492 & 93,508 & 109 & $3.345,086$ \\
300 & 83,680 & 107,320 & 109 & $3.687,939$ \\
\hline
\end{tabular}

Tabel 2. dan Tabel 3. menunjukkan hasil daya keluaran dan energi dari metode DEA dan metode Lagrange 
Multiplier untuk PLTG pada blok 2. Dapat dilihat hasil perbandingan simulasi antara metode optimisasi DEA dengan metode optimisasi Lagrange Multiplier memiliki jumlah energi yang sama disetiap permintaan daya dan konfigurasi generator yang tidak jauh berbeda. Dengan demikian metode optimisasi DEA merupakan metode yang dapat digunakan untuk solusi dari permasalahan economic dispatch pada sistem tenaga listrik.

\subsection{Hasil Simulasi DEA}

Pada sub bab ini akan membahas pengoperasian pembangkit yang optimal dengan memperhatikan batas minimum dan maksimum kapasitas generator. Hasil metode DEA secara diskret dan secara operasi sistem akan dibandingkan dengan pembebanan PLTGU Tambak Lorok .

\subsubsection{Hasil simulasi DEA secara diskret}

Gambar 9. menunjukkan hasil penjadwalan ekonomis unit PLTG di PLTGU Tambak Lorok yang hanya memperhatikan batas minimum dan maksimum kapasitas generator tanpa memperhatikan operasi sistem. Simulasi DEA secara diskret dilakukan pada data pembebanan satu hari tanggal 28 September 2017. Konversi dari total energi ke total biaya mengikuti nilai standar rata-rata supplier gas PT Indonesia Power Tambak Lorok Semarang yaitu 1 MMBTU= US\$7.

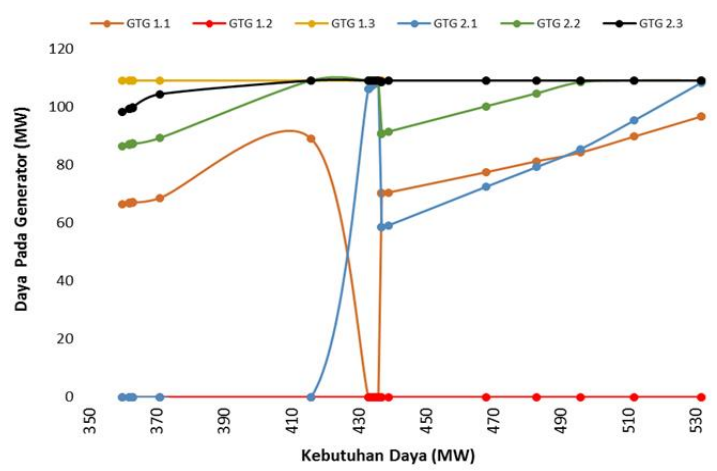

Gambar 9. Grafik operasi generator dengan metode DEA secara diskret

Dari Gambar 9. dapat dilihat bahwa pembebanan 4 generator saat permintaan daya $360 \mathrm{MW}$ sampai 416 MW generator yang aktif adalah GTG 1.1, GTG 1.3, GTG 2.2, dan GTG 2.3. Pembebanan 5 generator saat permintaan daya $437 \mathrm{MW}$ sampai $532 \mathrm{MW}$ generator yang aktif adalah GTG 1.1, GTG 1.3, GTG 2.1, GTG 2.2, dan GTG 2.3. Hasil pendistribusian daya pada generator aktif dengan metode DEA secara diskret lebih optimal dibandingkan dengan pengoperasian generator di PLTG pada PLTGU Tambak Lorok. Pendistribusian daya yang optimal pada generator dengan metode DEA secara diskret akan memberikan biaya pembangkitan yang lebih ekonomis.

\subsubsection{Hasil simulasi DEA secara operasi sistem}

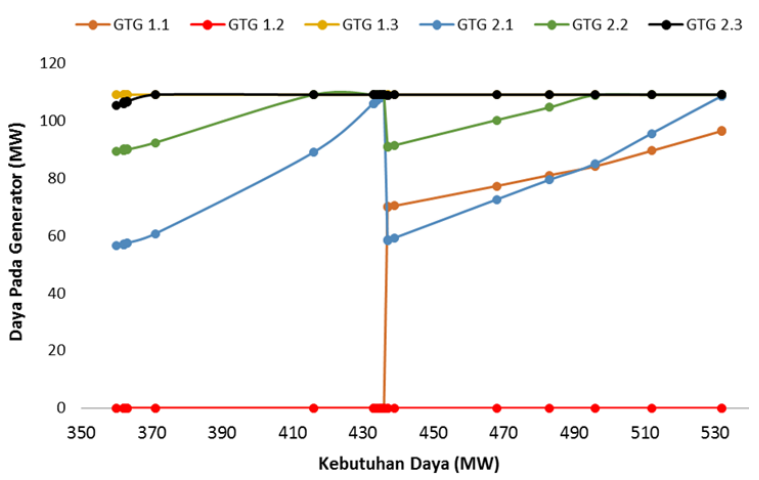

Gambar 10. Grafik operasi generator dengan metode DEA secara operasi sistem

Gambar 10. menunjukkan hasil penjadwalan ekonomis unit PLTG di PLTGU Tambak Lorok yang hanya memperhatikan batas minimum dan maksimum kapasitas generator serta memperhatikan operasi sistem. Operasi sistem berarti pembangkit listrik beroperasi secara kontinu setelah dinyalakan sesuai dengan bertambahnya permintaan daya dan berdasarkan konsumsi energi yang paling kecil.

Dari Gambar 10. dapat dilihat bahwa pembebanan 4 generator saat permintaan daya 360 MW sampai 436 MW generator yang aktif adalah GTG 1.3, GTG 2.1, GTG 2.2, dan GTG 2.3. Pembebanan 5 generator saat permintaan daya $437 \mathrm{MW}$ sampai $532 \mathrm{MW}$ generator yang aktif adalah GTG 1.1, GTG 1.3, GTG 2.1, GTG 2.2, dan GTG 2.3. Hasil pendistribusian daya pada generator aktif dengan metode DEA secara operasi sistem lebih optimal dibandingkan dengan pengoperasian generator di PLTG pada PLTGU Tambak Lorok. Pendistribusian daya yang optimal pada generator dengan metode DEA secara diskret akan memberikan biaya pembangkitan yang lebih ekonomis.

\subsection{Hasil Perbandingan Biaya Operasi Metode DEA Dengan Data Pembebanan PLTGU Tambak Lorok}

Perbandingan biaya operasi dilakukan antara biaya metode DEA operasi diskret terhadap biaya operasi pembebanan PLTGU Tambak Lorok dan juga perbandingan antara biaya metode operasi sistem terhadap biaya operasi pembebanan PLTGU Tambak Lorok.

\subsubsection{Perbandingan biaya hasil simulasi DEA secara diskret dengan pembebanan PLTGU Tambak Lorok}

Perbandingan biaya bahan bakar dalam \$/jam antara DEA operasi diskret dengan biaya pembebanan PLTGU Tambak Lorok ditunjukkan oleh Tabel 7. 
Tabel 7. Perbandingan biaya DEA operasi diskret dengan pembebanan PLTGU Tambak Lorok

\begin{tabular}{|c|c|c|c|}
\hline Daya (MW) & $\begin{array}{c}\text { Harga Tambak Lorok } \\
\text { (\$/Jam) }\end{array}$ & $\begin{array}{c}\text { Harga Operasi Diskret } \\
(\$ / J a m)\end{array}$ & $\begin{array}{l}\text { Selisih } \\
(\$ / J a m)\end{array}$ \\
\hline 439 & $37.371,394$ & $36.642,760$ & 728,634 \\
\hline 360 & $30.068,569$ & $29.340,654$ & 727,915 \\
\hline 362 & $30.196,450$ & $29.474,872$ & 721,577 \\
\hline 362 & $30.196,450$ & $29.474,872$ & 721,577 \\
\hline 362 & $30.196,450$ & $29.474,872$ & 721,577 \\
\hline 363 & $30.267,019$ & $29.542,018$ & 725 \\
\hline 363 & $30.267,019$ & $29.542,016$ & 725,003 \\
\hline 371 & $33.022,966$ & $30.080,120$ & $2.942,846$ \\
\hline 435 & $37.113,313$ & $34.513,262$ & $2.600,051$ \\
\hline 437 & $37.249,942$ & $36.507,604$ & 742,338 \\
\hline 434 & $37.074,239$ & $34.442,275$ & $2.631,964$ \\
\hline 433 & $37.003,810$ & $34.371,351$ & $2.632,459$ \\
\hline 433 & $37.003,810$ & $34.371,351$ & $2.632,459$ \\
\hline 416 & $35.817,225$ & $33.160,358$ & $2.656,867$ \\
\hline 435 & $37.144,738$ & $34.513,262$ & $2.631,476$ \\
\hline 437 & $37.266,615$ & $36.507,604$ & 759,011 \\
\hline 436 & $37.197,285$ & $34.584,319$ & $2.612,966$ \\
\hline 436 & $37.197,285$ & $34.584,319$ & $2.612,966$ \\
\hline 468 & $41.235,878$ & $38.616,781$ & $2.619,097$ \\
\hline 483 & $42.200,744$ & $39.648,329$ & $2.552,415$ \\
\hline 496 & $43.045,370$ & $40.548,137$ & $2.497,233$ \\
\hline 512 & $44.090,927$ & $41.664,511$ & $2.426,416$ \\
\hline 532 & $45.421,305$ & $43.076,425$ & $2.344,880$ \\
\hline 532 & $45.421,305$ & $43.076,425$ & $2.344,880$ \\
\hline 436 & $37.179,208$ & $34.584,319$ & $2.594,889$ \\
\hline \multicolumn{3}{|c|}{ Rata-rata } & $1.916,260$ \\
\hline
\end{tabular}

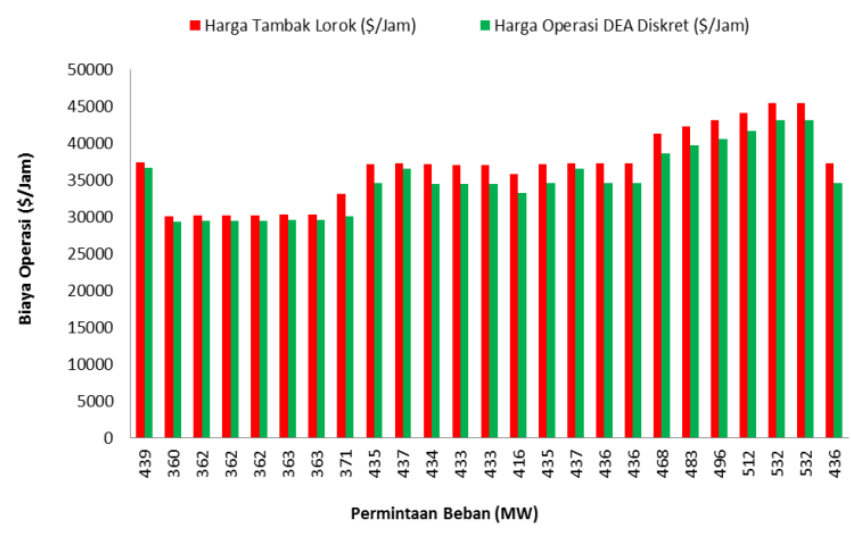

Gambar 11. Grafik selisih biaya metode DEA secara diskret dengan pembebanan PLTGU Tambak Lorok

Dari Tabel 7. dan Gambar 11. dapat dilihat bahwa untuk seluruh pembebanan, biaya operasi hasil optimisasi menggunakan metode DEA pada operasi diskret lebih hemat dari biaya operasi pembebanan PLTGU Tambak Lorok. Penghematan rata -rata sebesar 1916,260 \$/Jam, selisih biaya terbesar pada pembebanan $371 \mathrm{MW}$ dengan selisih biaya 2942,846 \$/Jam dan selisih biaya terkecil pada pembebanan $362 \mathrm{MW}$ dengan selisih biaya 721,577 $\$ /$ Jam.
3.3.2. Perbandingan biaya hasil simulasi DEA secara operasi sistem dengan pembebanan PLTGU Tambak Lorok

Perbandingan biaya bahan bakar dalam \$/jam antara DEA operasi sistem dengan biaya pembebanan PLTGU Tambak Lorok ditunjukkan oleh Tabel 8.

Tabel 8. Perbandingan biaya DEA operasi sistem dengan pembebanan PLTGU Tambak Lorok

\begin{tabular}{|c|c|c|c|}
\hline Daya (MW) & $\begin{array}{c}\text { Harga Tambak Lorok } \\
\text { (\$/Jam) }\end{array}$ & $\begin{array}{c}\text { Harga Operasi Sistem } \\
(\$ / \mathbf{J a m})\end{array}$ & Selisih (\$/Jam) \\
\hline 439 & $37.371,394$ & $36.642,76$ & 728,634 \\
\hline 360 & $30.068,569$ & $29.343,93$ & 724,639 \\
\hline 362 & $30.196,450$ & $29.478,79$ & 717,657 \\
\hline 362 & $30.196,450$ & $29.478,79$ & 717,657 \\
\hline 362 & $30.196,450$ & $29.478,79$ & 717,657 \\
\hline 363 & $30.267,019$ & $29.546,25$ & 720,768 \\
\hline 363 & $30.267,019$ & $29.546,25$ & 720,768 \\
\hline 371 & $33.022,966$ & $30.086,83$ & $2.936,140$ \\
\hline 435 & $37.113,313$ & $34.513,26$ & $2.600,051$ \\
\hline 437 & $37.249,942$ & $36.507,61$ & 742,333 \\
\hline 434 & $37.074,239$ & $34.442,28$ & $2.631,964$ \\
\hline 433 & $37.003,810$ & $34.371,35$ & $2.632,459$ \\
\hline 433 & $37.003,810$ & $34.371,35$ & $2.632,459$ \\
\hline 416 & $35.817,225$ & $33.176,44$ & $2.640,788$ \\
\hline 435 & $37.144,738$ & $34.513,26$ & $2.631,476$ \\
\hline 437 & $37.266,615$ & $36.507,61$ & 759,008 \\
\hline 436 & $37.197,285$ & $34.584,32$ & $2.612,966$ \\
\hline 436 & $37.197,285$ & $34.584,32$ & $2.612,966$ \\
\hline 468 & $41.235,878$ & $38.616,78$ & $2.619,097$ \\
\hline 483 & $42.200,744$ & $39.648,33$ & $2.552,415$ \\
\hline 496 & $43.045,370$ & $40.548,14$ & $2.497,233$ \\
\hline 512 & $44.090,927$ & $41.664,51$ & $2.426,416$ \\
\hline 532 & $45.421,305$ & $43.076,43$ & $2.344,880$ \\
\hline 532 & $45.421,305$ & $43.076,43$ & $2.344,880$ \\
\hline 436 & $37.179,208$ & $34.584,32$ & $2.594,889$ \\
\hline \multicolumn{3}{|c|}{ Rata-rata } & $1.914,408$ \\
\hline
\end{tabular}

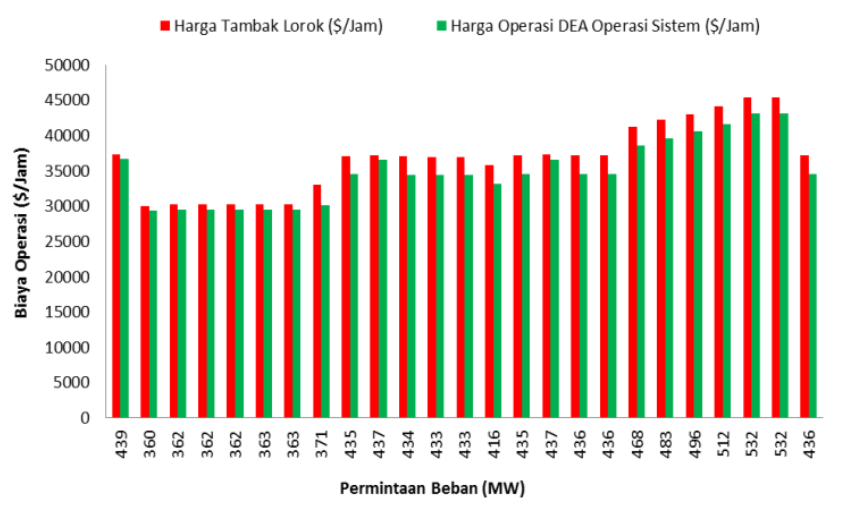

Gambar 12. Grafik selisih biaya metode DEA secara operasi sistem dengan pembebanan PLTGU Tambak Lorok

Dari Tabel 8. dan Gambar 12. dapat dilihat bahwa untuk seluruh pembebanan, biaya operasi hasil optimisasi menggunakan metode DEA pada operasi diskret lebih 
hemat dari biaya operasi pembebanan PLTGU Tambak Lorok. Penghematan rata -rata sebesar 1914,408 \$/Jam, selisih biaya terbesar pada pembebanan $371 \mathrm{MW}$ dengan selisih biaya 2936,140 \$/Jam dan selisih biaya terkecil pada pembebanan $362 \mathrm{MW}$ dengan selisih biaya 717,657 \$/Jam.

\section{Kesimpulan}

Dari hasil pengujian, metode optimisasi DEA dapat digunakan untuk solusi dari permasalahan penjadwalan ekonomis unit pembangkit PLTG di PLTGU Tambak Lorok. Ini dapat dilihat dari hasil perbandingan metode optimisasi DEA dengan Lagrange Multiplier pada percobaan permintaan daya $230 \mathrm{MW}, 265 \mathrm{MW}$, dan 300 MW memiliki total energi yang sama sebesar 3008,386 MMBTU/jam, 3345,086 MMBTU/jam, 3687,939 MMBTU/jam. Perbandingan biaya operasi optimisasi metode DEA operasi diskret lebih hemat dibandingkan dengan biaya operasi pembebanan PLTGU Tambak Lorok dengan rata-rata penghematan sebesar 1916,260 \$/Jam, selisih biaya terbesar pada pembebanan $371 \mathrm{MW}$ dengan selisih biaya 2942,846 \$/Jam dan selisih biaya terkecil pada pembebanan $362 \mathrm{MW}$ dengan selisih biaya 721,577 \$/Jam. Perbandingan biaya operasi optimisasi metode DEA operasi sistem lebih hemat dibandingkan dengan biaya operasi pembebanan PLTGU Tambak Lorok dengan rata- rata penghematan sebesar 1914,408 \$/Jam, selisih biaya terbesar pada pembebanan $371 \mathrm{MW}$ dengan selisih biaya 2936,140 \$/Jam dan selisih biaya terkecil pada pembebanan $362 \mathrm{MW}$ dengan selisih biaya 717,657 \$/Jam. Penelitian ini dapat dikembangkan dengan mempertimbangkan daya yang dihasilkan pada Turbin Uap (STG) dan mempertimbangkan rugi-rugi pada jaringan transmisi.

\section{Referensi}

[1]. D. Marsudi, Pembangkitan Energi Listrik, 2nd ed. Jakarta: Erlangga, 2011.

[2]. W. D. Stevenson Jr, Analisis Sistem Tenaga Listrik, 4th ed. Bandung: Erlangga, 1994

[3]. B. F. Wollenberg and W. A.J, Power Generation Operation and Control, 2nd ed. .

[4]. K. V. Price, R. S. Storn, and J. A. Lampinen, Differential Evolution - A Practical Approach to Global Optimization, vol. 1. New York: Springer, 2005.

[5]. R. S. Wibowo and I. Robandi, "Dynamic Economic Dispatch (DED) Menggunakan Differential Evolutionary (DE) Algorithm," no. 1, 2013.

[6]. I. D. Alber, "Metode Koloni Semut pada Domain Kontinu untuk Optimisasi Penjadwalan Ekonomis Unit Pembangkit PLTG di PLTGU PT Indonesia Power Tambak Lorok," Tek. Elektro Univ. Diponegoro, pp. 105-112, 2016.

[7]. F. J. Foreman, "Optimisasi Economic Dispatch pada Unit Pembangkit PLTG di PLTGU PT Indonesia Power Tambak Lorok Menggunakan Flower Pollination Algorithm," Transient, pp. 116-123, 2016.

[8]. Y. A. D. Wijaya, "Optimisasi Penjadwalan Ekononomis Pada Unit Pembangkit PLTG Di PLTGU PT Indonesia Power Tambak Lorok Menggunakan Metode Improved Whale Optimization Algorithm," Transient, pp. 1-11, 2017.

[9]. Ranisa, M. Facta, and Karnoto, "Perhitungan Pembebanan Pembangkit Di Kompleks Pltu Jabar Ii Sukabumi, Jawa Barat Dengan Metode Lagrange Multiplier Dan Kurva Kapabilitas Generator," Transient, vol. 4, no. 3, 2015.

[10]. J. Susilo, M. Facta, and S. Handoko, "Simulasi Perhitungan Pembebanan Ekonomis pada Pusat Listrik Tenaga Uap dan Gas dengan Metode Lagrange Multiplier (Studi Kasus di PT. Petrokimia Gresik)," Transient, vol. 3, no. 4, pp. 579-585, 2014.

[11]. D. Rumana, I. Hermawan, and M. Facta, "Implementasi Algoritma Genetik dalam," pp. 1-6.

[12]. H. D. Purnomo, "Differential Evolution," in Cara Mudah Belajar Metode Optimisasi Metaheuristik Menggunakan MatLab, Yogyakarta: Gava Media, 2014, p. 155. 